\title{
Cascading ecological effects caused by the establishment of the emerald ash borer Agrilus planipennis (Coleoptera: Buprestidae) in European Russia
}

\author{
MARINA J. ORLOVA-BIENKOWSKAJA
}

\begin{abstract}
A.N. Severtsov Institute of Ecology and Evolution, Russian Academy of Sciences, 33 Leninskiy Prospect, Moscow 119071, Russia;
\end{abstract} e-mail: marinaorlben@yandex.ru

Key words. Coleoptera, Buprestidae, Agrilus planipennis, Agrilus convexicollis, non-native species, biological invasion, common ash, EAB, Curculionidae, Scolytinae, Hylesinus varius, Cerambycidae, Tetrops starkii, Hymenoptera, Braconidae, Spathius polonicus

\begin{abstract}
Emerald ash borer, Agrilus planipennis, is a destructive invasive forest pest in North America and European Russia. This pest species is rapidly spreading in European Russia and is likely to arrive in other countries soon. The aim is to analyze the ecological consequences of the establishment of this pest in European Russia and investigate (1) what other xylophagous beetles develop on trees affected by A. planipennis, (2) how common is the parasitoid of the emerald ash borer Spathius polonicus (Hymenoptera: Braconidae: Doryctinae) and what is the level of parasitism by this species, and (3) how susceptible is the native European ash species Fraxinus excelsior to A. planipennis. A survey of approximately 1000 Fraxinus pennsylvanica trees damaged by A. planipennis in 13 localities has shown that Hylesinus varius (Coleoptera: Curculionidae: Scolytinae), Tetrops starkii (Coleoptera: Cerambycidae) and Agrilus convexicollis (Coleoptera: Buprestidae) were common on these trees. Spathius polonicus is frequently recorded. About 50 percent of late instar larvae of A. planipennis sampled were parasitized by S. polonicus. Maps of the distributions of T. starkii, A. convexicollis and S. polonicus before and after the establishment of $A$. planipennis in European Russia were compiled. It is hypothesized that these species, which are native to the West Palaearctic, spread into central European Russia after A. planipennis became established there. Current observations confirm those of previous authors that native European ash Fraxinus excelsior is susceptible to A. planipennis, increasing the threat posed by this pest. The establishment of $A$. planipennis has resulted in a cascade of ecological effects, such as outbreaks of other xylophagous beetles in A. planipennis-infested trees. It is likely that the propagation of $S$. polonicus will reduce the incidence of outbreaks of $A$. planipennis.
\end{abstract}

\section{INTRODUCTION}

An invasion of a non-native species of insect can by a cascading sequence of ecological effects affect the structure of an ecosystem (Kenis et al., 2009). In particular, the establishment of one non-native species sometimes makes an ecosystem more likely to be invaded by other non-native species (Simberloff \& Von Holle, 1999). The cascading ecological effects that resulted from the establishment of the emerald ash borer, Agrilus planipennis Fairmaire (Coleoptera: Buprestidae), in European Russia is described in the present article.

Agrilus planipennis is one of the most destructive forest pests in the world (Aukema et al., 2011). This beetle originates from East Asia: Northeastern China, Korea, Japan, Taiwan and Russian Far East (Jendek, 1994; Wei et al., 2007). It was inadvertently introduced into North America in the 1990s (Siegert et al., 2014) and has destroyed tens of millions of ash trees there (Aukema et al., 2011). Agrilus planipennis was first collected in Europe in 2003 in Moscow (Izhevskii \& Mozolevskaya, 2010). To date, more than $80 \%$ of the ash trees in Moscow have been destroyed by this pest and there are additional infestations in 11 regions in central European Russia (Orlova-Bienkowskaja, 2013, 2014a, b; Baranchikov, 2013; Straw et al., 2013), but our understanding of the ecological effect of $A$. planipennis outbreak is limited.

In European Russia A. planipennis develops mainly on Fraxinus pennsylvanica Marsh. (Baranchikov et al., 2008), which was introduced from North America about 100 years ago. It is one of the most common trees in urban plantations. In particular, it makes up about $20 \%$ of the trees in Moscow (Majorov et al., 2012; Vinogradova et al., 2010). Agrilus planipennis prefers some species of ash over others (Wei et al., 2007; Anulewicz et al., 2008). It is important to know if $F$. excelsior is susceptible to $A$. planipennis, because $F$. excelsior is common and an important component of the biodiversity in European forests (FRAXIGEN, 2005; Mitchell et al., 2014).

Fraxinus excelsior is rare in central European Russia, with only individual trees occurring in urban plantations. The broad-leaved forests with $F$. excelsior occur in the southern parts of European Russia, in the Kursk region in particular, where $A$. planipennis has not yet been recorded. It has, however, been detected very close to broad-leaved forests in the Tula region (Straw et al., 2013; Orlova-Bienkowskaja, 2014a). Straw et al. (2013) and Baranchikov et al. (2014) record $F$. excelsior trees damaged by $A$. planipennis in Moscow. Additional records of $F$. excelsior damaged by $A$. planipennis in Moscow, Voronezh, Tula and Orel are presented in the present article.

The insect fauna encountered on Fraxinus in the centre of European Russia, especially in the Moscow region, is well-described (Nikitsky et al., 1996; Mozolevskaya et al., 2010). About 20 species of insects (Coleoptera, Lepidoptera, Hymenoptera and Diptera) are common on ash. Hylesinus varius (Coleoptera: Curculionidae: Scolytinae) 
was the only species of xylophagous beetle known to develop on ash in the Moscow region before the arrival of $A$. planipennis. After the establishment of $A$. planipennis, two more species of xylophagous beetle were recorded: Agrilus convexicollis Redtenbacher (Coleoptera: Buprestidae) (Nikitsky, 2009; Vlasov, 2010) and Tetrops starkii Chevrolat (Coleoptera: Cerambycidae) (Danilevsky, 2012). It is hypothesized that the extent of the range of $A$. convexicollis, which develops in dead ash branches, has increased as a result of ash canopy decline caused by $A$. planipennis (Orlova-Bienkowskaja \& Volkovitsh, 2014), but the effect of A. planipennis on other xylophagous beetles has not been studied.

Spathius polonicus Niezabitowski (Hymenoptera: Braconidae: Doryctinae) is the first species of parasitoid recorded attacking A. planipennis (Orlova-Bienkowskaja \& Belokobylskij, 2014) in Europe, but there is little information about its distribution, phenology and the rate of parasitism.

The aim of this study is to analyze the ecological consequences of the establishment of $A$. planipennis in central European Russia and to answer the following questions: (1) What other xylophagous beetles develop on ash infested with A. planipennis?; (2) how common is the emerald ash borer parasitoid, Spathius polonicus, and what percentage of the emerald ash borer larvae are parasitized by this parasitoid?; and (3) how susceptible is the native European ash, Fraxinus excelsior, to attack by $A$. planipennis?

\section{MATERIAL AND METHODS}

574 larvae, pupae and adults of xylophagous beetles and parasitoids were collected from about 1000 trees of $F$. pennsylvanica severely damaged by $A$. planipennis at 13 localities in European Russia in 2013 and 2014 (Table 1). Parasitoids were collected from the remains of $A$. planipennis larvae found under the bark in the lower part of stems up to $1.5 \mathrm{~m}$ from the ground. For this purpose, the lower $1.5 \mathrm{~m}$ of trunks of standing trees was debarked using a chisel and hammer. Larvae and pupae of xylophagous beetles were collected from under the bark of branches and thin upper parts of stems and preserved in alcohol. Adults were collected from leaves, branches and stems. About 100 trees in the Moscow region were regularly surveyed for adults twice a week from 15.v.2014 to 19.vii.2014. Dates of additional surveys in other regions are indicated in Tables 3, 4 and 5. Sweep nets and sticky bands were used, but the most effective way of sampling was collecting from leaves by hand. All specimens (adults, larvae and pupae) were examined under a microscope in the laboratory and deposited in the author's collection.

The distributions of $T$. starkii Chevrolat (Coleoptera: Cerambycidae), A. convexicollis Redtenbacher (Coleoptera: Buprestidae) and S. polonicus Niezabitowski (Hymenoptera: Braconidae: Doryctinae) before and after the establishment of $A$. planipennis are mapped. The information about records of these insects was compiled by examining 86 literature sources and collecting data from specimens deposited in the Zoological Institute of the Russian Academy of Sciences, St. Petersburg (ZIN) and Moscow State Pedagogical University (MSPU). In addition, I mapped my records of these insects in Moscow, Yaroslavl and Lipetsk regions in summer 2013 and 2014. Seventy-three localities for A. planipennis, 480 localities for $A$. convexicollis, 284 localities for $T$. starkii and 8 localities for $S$. polonicus are mapped. Maps of recent finds of $T$. starkii, A. convexicollis, and S. polonicus are compared with the map of the known A. planipennis distribution in European Russia. The program DIVA-GIS Version 7.5 (Hijmans, 2011) was used to generate the maps.

To determine how susceptible the native $F$. excelsior is to $A$. planipennis, $34 \mathrm{~F}$. excelsior trees were examined in four cities. The sample size was limited because $F$. excelsior is rare in central European Russia. The trees were observed from ground level.

Abbreviations used in figures: AZ - Azerbaijan, AD - Adygea, $\mathrm{AR}$ - Armenia, BE - Belgium, BY - Belarus, CR - Crimea, CZ Czech Republic, DA - Dagestan, IR - Iran, IT - Italy, K - Kaluga region, KA - Karachay-Cherkessia, KE - Kemerovo region, KR - Krasnodar territory, L - Lipetsk region, $\mathrm{M}$ - Moscow region, NL - Netherlands, O - Orel region, PL - Poland, R - Ryazan region, RO - Rostov region, $\mathrm{S}-$ Smolensk region, $\mathrm{SE}-\mathrm{Serbia}$, SL - Slovakia, SP - Spain, ST - Stavropol territory, SZ - Switzerland, TA - Tambov region, TD - Tadjikistan, TU - Tula region, TR - Turkmenistan, TV - Tver region, UK - Ukraine, UZ - Uzbekistan, VL - Vladimir region, VOL - Volgograd region, VOR - Voronezh region, Y - Yaroslavl region.

TABLE 1. Locations sampled.

\begin{tabular}{lcccrc}
\hline Localities & Coordinates & $\begin{array}{c}\text { Approximate no. } \\
\text { of trees surveyed } \\
\text { for adults }\end{array}$ & $\begin{array}{c}\text { Approximate no. } \\
\text { of trees dissected to } \\
\text { find larvae and pupae }\end{array}$ & $\begin{array}{c}\text { A. planipennis } \\
\text { collected }\end{array}$ & $\begin{array}{c}\text { No. of specimens } \\
\text { of other species } \\
\text { collected }\end{array}$ \\
\hline Zelenograd, 11th district & $56.00^{\circ} \mathrm{N}, 37.18^{\circ} \mathrm{E}$ & 300 & 20 & 71 & 179 \\
Zelenograd, 16th district & $55.97^{\circ} \mathrm{N}, 37.16^{\circ} \mathrm{E}$ & 100 & 10 & 36 & 29 \\
Zelenograd, Georgievsky prospect & $55.98^{\circ} \mathrm{N}, 37.21^{\circ} \mathrm{E}$ & 10 & 10 & 1 & 5 \\
Zelenograd, Panfilova street & $55.98^{\circ} \mathrm{N}, 37.17^{\circ} \mathrm{N}$ & 50 & 10 & 35 & 38 \\
Monino & $55.84^{\circ} \mathrm{N}, 38.20^{\circ} \mathrm{E}$ & 100 & 0 & 0 & 3 \\
Uzunovo & $54.55^{\circ} \mathrm{N}, 38.62^{\circ} \mathrm{E}$ & 50 & 0 & 1 & 3 \\
Yaroslavl & $57.63^{\circ} \mathrm{N}, 39.87^{\circ} \mathrm{E}$ & 100 & 20 & 16 & 4 \\
Moscow, VILAR & $55.56^{\circ} \mathrm{N}, 37.59^{\circ} \mathrm{E}$ & 100 & 10 & 5 & 13 \\
Staraya Kupavna & $55.81^{\circ} \mathrm{N}, 38.18^{\circ} \mathrm{E}$ & 100 & 0 & 9 \\
Gryazi & $52.49^{\circ} \mathrm{N}, 39.93^{\circ} \mathrm{E}$ & 20 & 50 & 75 & 1 \\
Planernaya & $55.92^{\circ} \mathrm{N}, 37.38^{\circ} \mathrm{E}$ & 0 & 10 & 2 & 23 \\
Povarovka & $56.07^{\circ} \mathrm{N}, 37.07^{\circ} \mathrm{E}$ & 20 & 5 & 3 & 9 \\
Solnechnogorsk & $56.19^{\circ} \mathrm{N}, 36.98 \mathrm{E}$ & 20 & 145 & 246 & 12 \\
\hline Total number & & 970 & & 328 \\
\hline
\end{tabular}


TABLE 2. Localities of Tetrops starkii in its native range.

\begin{tabular}{|c|c|c|c|}
\hline Region* & $\begin{array}{l}\text { No. of mapped } \\
\text { localities }\end{array}$ & $\begin{array}{l}\text { Years when } \\
\text { collected }\end{array}$ & Sources of information \\
\hline Austria & 23 & $1888-2001$ & Horion, 1974; Holzschuh, 1981; Geiser, 2001, GBIF, 2013 \\
\hline Azerbaijan & 1 & pre 1928 & Danilevsky, 2014 \\
\hline Belarus & 0 & pre 1997 & Danilevsky, 2014 \\
\hline Belgium & 3 & 2012 & Drumont et al., 2012 \\
\hline Bosnia Herzegovina & 0 & pre 2010 & Löbl \& Smetana, 2010 \\
\hline Bulgaria & 6 & pre $1931-2005$ & $\begin{array}{l}\text { Horion, 1974; Holzschuh, 1981; Migliaccio et al., 2007; } \\
\text { Georgiev et al., 2005; pers. commun. by G. Georgiev }\end{array}$ \\
\hline Croatia & 0 & pre 2010 & Löbl \& Smetana, 2010 \\
\hline Czech Republic & 43 & pre 1929-2007 & $\begin{array}{l}\text { Roubal, 1929; Holzschuh, 1981; Sláma, 1998; Hoskovec, 2007; } \\
\text { Coleoptera Poloniae, } 2014 \text { and examined specimens from ZIN** }\end{array}$ \\
\hline Denmark & 5 & $1913-1989$ & $\begin{array}{l}\text { Danmarks Fugle og Natur, 2014; Fagdatacenter for Biodiversitet } \\
\text { og Terrestrisk Natur, } 2007\end{array}$ \\
\hline France & 40 & pre $1958-2002$ & Horion, 1974; Schmeltz, 2002; Cocquempot, 2011 \\
\hline Germany & 21 & pre 1995 & Horion, 1974; Bense, 1995 \\
\hline Great Britain & 5 & $1991-1997$ & Welch, 2003; GBIF, 2013 \\
\hline Greece & 0 & pre 2010 & Löbl \& Smetana, 2010 \\
\hline Hungary & 10 & pre 1971-2003 & Lőkkös, 2010 \\
\hline Italy & 7 & pre $1927-2009$ & $\begin{array}{c}\text { Roubal, 1929; Horion, 1974; Bellavista et al., 2009; } \\
\text { Sama \& Rapuzzi, 2011; Hellrigl et al., 2012; GBIF, } 2013\end{array}$ \\
\hline Ireland & 0 & pre 2010 & Löbl \& Smetana, 2010 \\
\hline Latvia & 0 & pre 2010 & Löbl \& Smetana, 2010 \\
\hline Macedonia & 1 & 1971 & Holzschuh, 1981 \\
\hline Moldova & 1 & pre 1927 & Roubal, 1929 \\
\hline Netherlands & 7 & $1968-2013$ & Horion, 1974; Waarneming.nl, 2014 \\
\hline Norway & 4 & $1934-2008$ & Horion, 1974; GBIF, 2013 \\
\hline Poland & 11 & pre $1928-2005$ & Starzyk \& Lessaer, 1978; GBIF, 2013; Coleoptera Poloniae, 2014 \\
\hline Romania & 5 & $1895-1965$ & Holzschuh, 1981; Starzyk \& Lessaer, 1978; Serafim, 2010 \\
\hline Russia, Kaliningrad region & 1 & 2014 & Pers. commun. by V. Alekseev \\
\hline Russia, Krasnodar region & 2 & 1986 & Nikitsky et al., 2008; Danilevsky, 2012 and examined specimens from ZIN \\
\hline Russia, Rostov region & 1 & 1951 & Examined specimens from MSPU $* * *$ \\
\hline Russia, Voronezh region & 1 & 1960 & Examined specimens from MSPU \\
\hline Russia, Republic of Crimea & 1 & 1910 & Examined specimens from ZIN \\
\hline Serbia & 2 & pre 1974-2009 & Starzyk \& Lessaer, 1978; Gnjatović \& Žikić, 2010 \\
\hline Slovakia & 28 & pre 1929-1991 & $\begin{array}{l}\text { Roubal, 1929; Holzschuh, 1981; Sláma, 1998; } \\
\text { Lamiaires du Monde, } 2014 \text { and examined specimens from ZIN }\end{array}$ \\
\hline Slovenia & 9 & $1926-1987$ & Brelih et al., 2006 \\
\hline Spain & 1 & 2002 & Sobrino \& Sánchez, 2003 \\
\hline Sweden & 21 & $1947-2013$ & GBIF, 2013 \\
\hline Switzerland & 19 & $1951-2012$ & CSCF-karch, 2013 \\
\hline Ukraine & 4 & 1911 & Pers. commun. by A. Miroshnikov and examined specimens from ZIN \\
\hline
\end{tabular}

* Besides these regions T. starkii was recorded in Central Georgia (Starzyk \& Lessaer, 1978), but Danilevsky (2014) proved that this record referred to another species. Tamutis et al. (2011) presumed, that T. starkii could occur in Lithuania, but there are no documented records. ** ZIN - Zoological Institute of the Russian Academy of Sciences. *** MSPU - Moscow State Pedagogical University.

\section{RESULTS}

\section{What other xylophagous beetles develop in ash trees attacked by $A$. planipennis?}

The survey of ash trees attacked by A. planipennis revealed that three species of xylophagous beetles are common: T. starkii, A. convexicollis and H. varius. Tetrops starkii is widely distributed in the Western Palaearctic, from Great Britain in the west to Azerbaijan in the east, and from Sweden in the north to Sicily in the south (Table 2, Fig. 1). In European Russia, it has been previously recorded only in the south: Krasnodar region, Rostov region,
Voronezh region and Crimea. In central European Russia, however, it was first recorded only a few years ago, namely in the Moscow region in 2012 (Danilevsky, 2012) and in Yaroslavl in 2008 (D. Vlasov, pers. commun.), so the known distribution of $T$. starkii has recently increased by $700 \mathrm{~km}$ to the north. T. starkii was collected by the author at three localities in the Moscow region including Zelenograd, where it is a common species (Table 3, Fig. 1). In all cases, $T$. starkii were collected on ash trees severely damaged by $A$. planipennis.

Tetrops starkii is known to feed on F. excelsior (Starzyk \& Lessaer, 1978), F. ornus L. (Georgiev et al., 2005) and F. 


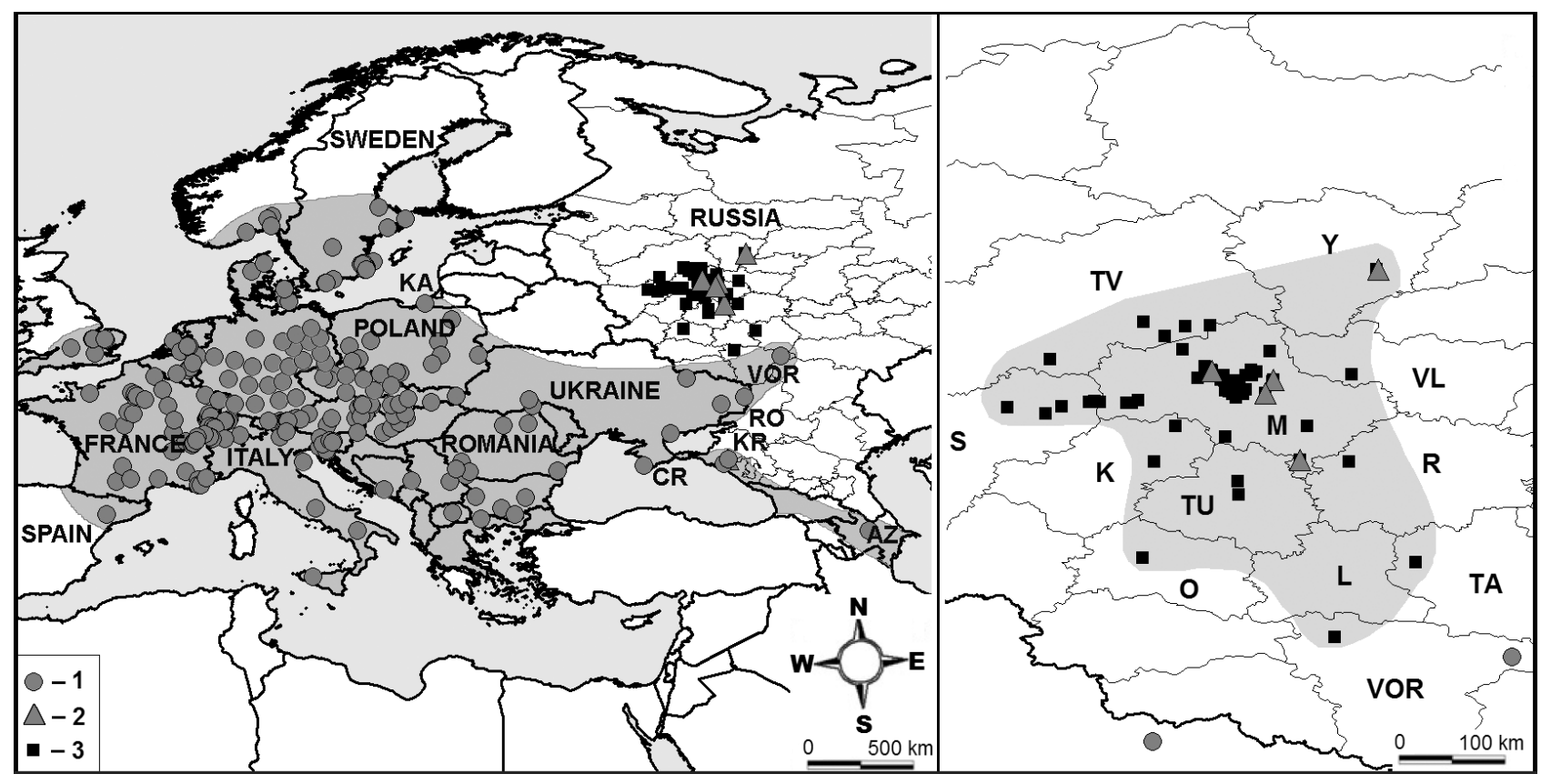

Fig. 1. The known distributions of Tetrops starkii (Coleoptera: Cerambycidae) and Agrilus planipennis (Coleoptera: Buprestidae) in Europe in 2014. Left hand map: the whole distribution, right hand map: the distribution in the centre of European Russia. 1 - records of T. starkii within its native distribution. 2 - localities where T. starkii are recorded outside its native distribution (all records for 2008-2014). 3 - localities, where A. planipennis are recorded. Native distribution of T. starkii is shaded in the left hand map and the area recently occupied by $A$. planipennis in the right hand map. Sources of information are listed in Tables 1 and 2. The localities of A. planipennis in Figs 1-3 are those cited by Orlova-Bienkowskaja (2014) with some new localities. Abbreviations: see "Material and methods".

angustifolia Vahl (Bellavista et al., 2009). At all localities examined in central European Russia, adults of T. starkii were collected on $F$. pennsylvanica. In addition, 18 pupae of T. starkii were collected from dead branches of $F$. pennsylvanica, which is a new host record for T. starkii.

In the Moscow region, adult T. starkii beetles were collected from late May to mid July (Table 3). Adults are active in daytime and occur on leaves both in sunny and cloudy weather and even when it is raining. Live hibernating $T$. starkii pupae were collected in winter and early spring from dead branches of $F$. pennsylvanica. It is known that in its native range $T$. starkii often occurs on the same trees as A. convexicollis (Starzyk \& Lessaer, 1978). In the centre of European Russia, these species also coexist on $F$. pennsylvanica damaged by $A$. planipennis.

The distribution of $A$. convexicollis was recently described in detail based on the examination of 29 museum specimens and 48 literature sources (Orlova-Bienkowskaja $\&$ Volkovitsh, 2014). This species occurs in many European and Mediterranean countries, from Spain to Azerbaijan. In European Russia, it was previously recorded only in the south (Adygea, Dagestan, Karachay-Cherkessia, Krasnodar territory, Rostov region, Stavropol territory, Volgograd region and Voronezh region). Before 2007 it had not been recorded in central European Russia, but since 2007 specimens of A. convexicollis have been collected at 9 central European Russia localities in the Moscow, Lipetsk and Yaroslavl regions (Fig. 2, Table 4), effectively extending the northern border of the previously known distribution by approximately $665 \mathrm{~km}$. In all cases but one, $A$. convexicollis was collected on ash trees with signs of $A$. planipennis infestation.

In Western Europe, A. convexicollis develops mainly in recently dead shoots and branches of ash trees: F. excelsior,

TABLE 3. Localities where Tetrops starkii was recently recorded in central European Russia.

\begin{tabular}{lccc}
\hline Collection localities & Dates & No. of specimens & Source of information \\
\hline Yaroslavl & $21.6 .2008,18.6 .2014$ & 4 adults & $\begin{array}{c}\text { One examined specimen collected by D. Vlasov } \\
\text { and pers. commun. by D. Vlasov }\end{array}$ \\
\hline Bykovo & 6.2012 & 31 adults & Danilevsky (2012) \\
\cline { 2 - 3 } Zelenograd & $1.6 .-3.7 .2013$ and $26.5-12.7 .2014$ & more than 100 adults & Pers. commun. by M. Danilevsky \\
\cline { 2 - 3 } & $19.11 .2013,27.3 .2014,16.04 .2014$ & 18 adults & \\
\hline Monino & 21.6 .2013 & \multirow{2}{*}{ Specimens collected by the author } \\
\hline Uzunovo & 29.6 .2013 & & \\
\hline
\end{tabular}




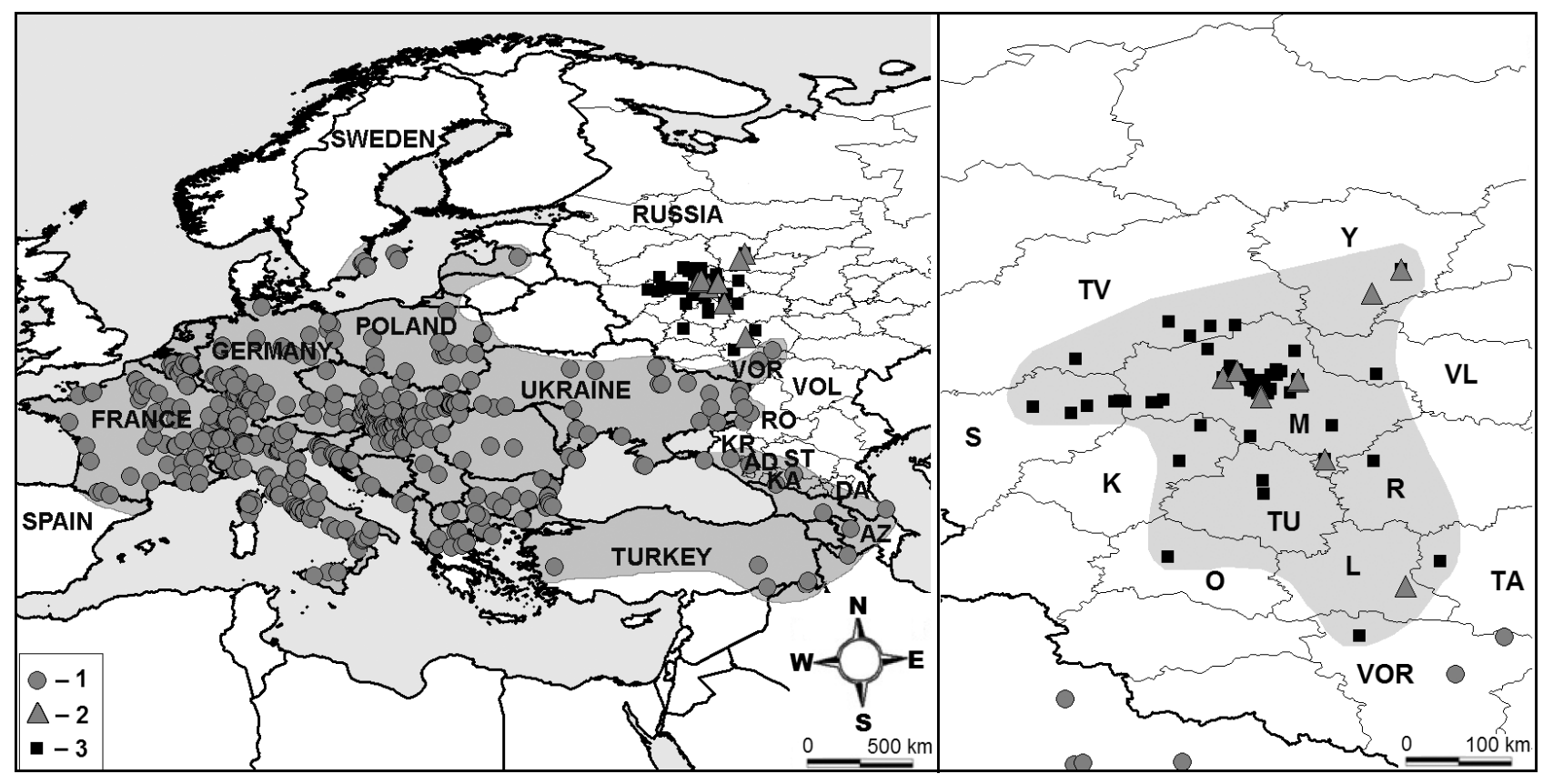

Fig. 2. The known distributions of Agrilus convexicollis and A. planipennis (Coleoptera: Buprestidae) in Europe in 2014. Left hand map is of the whole distribution, right hand map is its distribution in the centre of European Russia. 1 - records of $A$. convexicollis within its native distribution. 2 - localities where A. convexicollis is recorded outside its native distribution (records for 2007-2014). 3 - localities, where A. planipennis is recorded. Native distribution of $A$. convexicollis is shaded in the left hand map and the area recently occupied is in the right hand map. Abbreviations: see Fig. 1. The distribution of A. convexicollis is based on Orlova-Bienkowskaja \& Volkovitsh (2014) with additional localities (see Table 4).

F. ornus and F. oxyphylla as well as some other plants of the family Oleaceae (Brechtel \& Kostenbader, 2002). Rcently, F. pennsylvanica was recorded as a host plant (OrlovaBienkowskaja \& Volkovitsh, 2014). All specimens of $A$. convexicollis collected in central European Russia were on $F$. pennsylvanica. Fifteen larvae were collected from under the bark of the upper parts of the trunks of $F$. pennsylvani$c a$. In addition, one adult beetle that died in its emergence hole was also found. The flight period of $A$. convexicollis lasts from early June to mid July (Table 4).
Hylesinus varius is a native pest of ash (Stark, 1952). The current outbreak of $H$. varius was first recorded in 2002 (Izhevskii \& Mozolevskaya, 2010). In this study, larval galleries, adults and larvae of $H$. varius were recorded in trunks and branches of $F$. pennsylvanica at seven localities in the Moscow region. The percentage of trees damaged by $H$. varius is estimated to be between 10 and $60 \%$. The adult flight period is in May. New adults were recorded in the bark from the middle of August to the end of April. Hylesinus varius occurs mainly in the same trees

TABLE 4. Localities where Agrilus convexicollis was recently recorded in central European Russia.

\begin{tabular}{|c|c|c|c|c|}
\hline Localities & Dates & $\begin{array}{c}\text { No. of } \\
\text { specimens }\end{array}$ & $\begin{array}{l}\text { Was the tree damaged } \\
\text { by } A . \text { planipennis? }\end{array}$ & Source of information \\
\hline Yaroslavl & 2007 and 30.6 .2013 & 4 adults & Yes & $\begin{array}{l}\text { Vlasov (2010) and specimens } \\
\text { collected by the author }\end{array}$ \\
\hline Rostov (Yaroslavl Region) & 2007 & 1 adult & & Pers. commun. by D. Vlasov \\
\hline Manikhino & 15.6.2008 & 1 adult & Yes & Nikitsky (2009) \\
\hline Zelenograd & $\begin{array}{c}1.6 .2013-5.7 .2013 \\
2.6-16.7 .2014\end{array}$ & $\begin{array}{l}74 \text { adults, } \\
12 \text { larvae }\end{array}$ & Yes & \multirow{6}{*}{$\begin{array}{l}\text { Specimens collected } \\
\text { by the author }\end{array}$} \\
\hline Moscow, Botanical garden of VILAR & 19.6.2014 & $\begin{array}{l}3 \text { adults, } \\
3 \text { larvae }\end{array}$ & Yes & \\
\hline Staraya Kupavna & 21.6 .2013 & 9 adults & Yes & \\
\hline Monino & 21.6 .2013 & 2 adults & Yes & \\
\hline Uzunovo & 29.6 .2013 & 1 adult & Yes & \\
\hline Gryazi & 27.6 .2013 & 1 adult & No & \\
\hline Total number & & $\begin{array}{l}95 \text { adults, } \\
15 \text { larvae }\end{array}$ & & \\
\hline
\end{tabular}




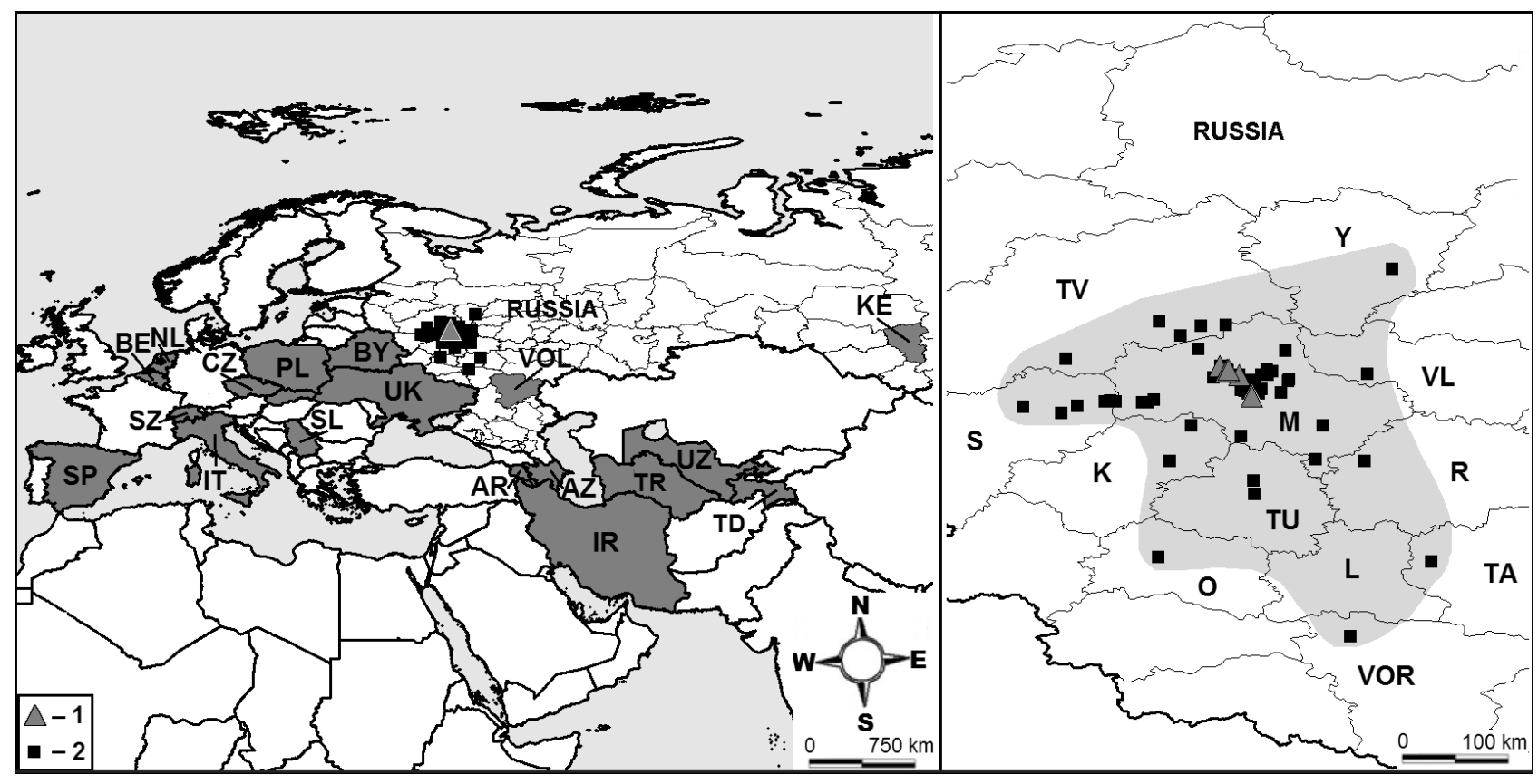

Fig. 3. The known distribution of Spathius polonicus (Hymenoptera: Braconidae) and the area recently occupied by A. planipennis (Coleoptera: Buprestidae) in Europe in 2014. Left hand map is the whole distribution, right hand map is distribution in the centre of European Russia. 1 - records of S. polonicus reported in 2013-2014. 2 - localities, where A. planipennis is recorded. Countries and regions where $S$. polonicus is recorded are shaded in the left hand map and the area recently occupied by A. planipennis is shaded in the right hand map. Sources of information are listed in Table 5.

as A. planipennis, but there are also occasionally individual trees severely damaged or even killed by $H$. varius without any signs of infestation by $A$. planipennis. The proportion of such trees in Zelenograd is about 5\%.

How common is the parasitoid Spathius polonicus and what is the extent of parasitism of the emerald ash borer A. planipennis by this species?

Spathius polonicus is an ectoparasitoid of buprestid larvae (Belokobylskij, 2003). Recently, it was discovered that it can parasitize $A$. planipennis (Orlova-Bienkowskaja \& Belokobylskij, 2014). Spathius polonicus is a widely distributed Western Palaearctic species (Fig. 3). It occurs in Spain, Netherlands, Switzerland, Italy, Poland, Czech Republic, Slovakia, Serbia, Belarus, Ukraine, Russia, Armenia, Azerbaijan, Turkmenistan, Uzbekistan, Tadjikistan, Iran (Belokobylskij, 2003) and Belgium (Belgian Species List, 2014). It had not been recorded in the centre of European Russia before 2013. The only previously known locality in European Russia is in the southeastern part: in the Volgograd region (Belokobylskij, 1989). In 2013-2014, S. polonicus was found at eight localities in the Moscow region (Table 5, Fig. 3). The distance between the two most distant localities is about $78 \mathrm{~km}$. So $S$. polonicus is common and rather widely distributed in the region of the outbreak of $A$. planipennis.

I have collected 129 live specimens (adults in cocoons, larvae and pupae) of $S$. polonicus associated with late instar A. planipennis under the bark of trunks. I found the remains of $56 \mathrm{~A}$. planipennis larvae killed by $S$. polonicus and 51 live late instar larvae. With about $50 \%$ of the specimens sampled parasitized the percentage parasitism is probably quite high. Remains of $A$. planipennis larvae killed by $S$. polonicus typically consist of the head capsule, prothorax and a pair of urogomphi connected by a thin "thread" (remains of the body) (Fig. 4). Sometimes the dead A. planipennis larvae found with cocoons of $S$. polonicus were not completely consumed. Up to six specimens of $S$. polonicus develop on one larva of $A$. planipennis. They can be at different stages of development. Sometimes larvae, pupae and adults in cocoons occur simultaneously on the same A. planipennis larva. Cocoons are built close to each other. In winter, hibernating $S$. polonicus pupae and larvae in cocoons were collected from under the bark (Table 5). Adult S. polonicus were captured on leaves in June-July.

What other insects are connected with $F$. pennsylvanica attacked by $A$. planipennis?

Adults of Coeloides melanotus Wesmael (Braconinae) are very common on leaves of $F$. pennsylvanica in the Moscow region. Seven adults of this species were reared from pieces of dead branches of $F$. pennsylvanica collected 16 April 2014. There were also larval galleries of T. starkii and $H$. varius in these branches. It is known that $C$. melanotus parasitizes H. varius (Elton, 1966). Eight larvae of A. convexicollis were killed by unidentified braconid parasitoids. Six pupae and 7 larvae of these parasitoids were collected. On 19 July 2014 one pupa of an unknown hymenopteran parasitoid was found within the cocoon of $S$. polonicus. Some insects, in particular Anthonomus pomorum L. (Curculionidae), use the galleries of $A$. planipennis or space under loose bark of $F$. pennsylvanica as a shelter. Other species use the larval galleries as a breeding site. For example, the wasp Passoloecus corniger Shuckard (Hy- 


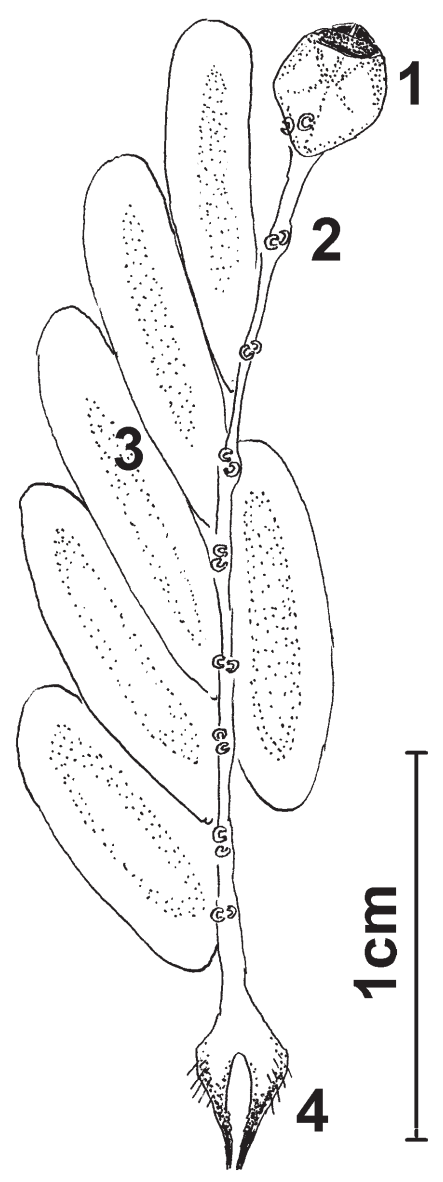

Fig. 4. Remains of a larva of Agrilus planipennis with cocoons of the ectoparasitoid Spathius polonicus. 1 - head capsule and prothorax; 2 - remains of cuticle with spiracles; 3 - cocoons of the ectoparasitoid; 4 - urogomphi. menoptera: Sphecidae) makes nests in larval galleries of $A$. planipennis in trunks of $F$. pennsylvanica, and the smaller wasp Passoloecus brevilabris Wolf (Hymenoptera: Sphecidae) make nests in larval galleries of $A$. convexicollis in dead branches.

\section{How susceptible to attack by $A$. planipennis is the native species of European ash, Fraxinus excelsior?}

The survey of 34 trees of landscaped ash F. excelsior in four cities where $A$. planipennis was present revealed that 28 of them have emergence holes of $A$. planipennis (Table 6). All trees with signs of $A$. planipennis infestation were severely damaged. Many branches and sometimes the upper parts of trunks were dead. Larvae of $A$. planipennis were collected from under the bark of $F$. excelsior.

\section{DISCUSSION}

Invasive plants, which change the character of ecosystems, are termed transformers (Richardson et al., 2000). Agrilus planipennis is an example of such an insect. It significantly changed the community connected with $F$. pennsylvanica in central European Russia. The scheme of ecological effects connected with the establishment of $A$. planipennis is shown in Fig. 5.

It is known that $A$. planipennis thrives on $F$. pennsylvanica (Wei et al., 2007; Anulewicz et al., 2008) and readily colonizes it, causing an outbreak. Outbreaks have occurred in North America where $F$. pennsylvanica is native and $A$. planipennis is non-native (Aukema et al., 2011), in China where $F$. pennsylvanica is non-native and A. planipennis is native (Wei et al., 2007) and in European Russia where both species are non-native (Volkovitsh \& Mozolevskaya,

TABLE 5. Specimens of S. polonicus collected with the remains of larvae of A. planipennis from under the bark of $F$. pennsylvanica in the Moscow region.

\begin{tabular}{|c|c|c|c|c|}
\hline Locality & $\begin{array}{l}\text { Date of } \\
\text { collection }\end{array}$ & Collected specimen of S. polonicus & $\begin{array}{c}\text { No. of } A \text {. planipennis last } \\
\text { instar larvae killed by } S \text {. } \\
\text { polonicus }\end{array}$ & $\begin{array}{l}\text { No. of live } A \text {. planipen- } \\
\text { nis last instar larvae and } \\
\text { prepupae }\end{array}$ \\
\hline \multirow{2}{*}{$\begin{array}{l}\text { Zelenograd, } \\
\text { 11th district }\end{array}$} & 1. -2.10 .2013 & 12 larvae in cocoons, 1 pupa & 2 & 8 \\
\hline & 29.10 .2013 & 4 larvae in cocoons, 1 pupa & 1 & 1 \\
\hline \multirow{2}{*}{$\begin{array}{l}\text { Zelenograd, } \\
\text { 16th district }\end{array}$} & 30.10 .2013 & 20 larvae in cocoons & 3 & 4 \\
\hline & 11.3.2014 & 9 adults in cocoons & 1 & 2 \\
\hline \multirow[t]{2}{*}{$\begin{array}{l}\text { Zelenograd, Georgievsky } \\
\text { prospect }\end{array}$} & 4.5 .2014 & $\begin{array}{c}2 \text { adults in cocoons, } \\
2 \text { larvae in cocoons, } 1 \text { pupa }\end{array}$ & 3 & 1 \\
\hline & 4.6 .2014 & 8 adults in cocoons, 7 larvae & 5 & 6 \\
\hline \multirow[t]{2}{*}{$\begin{array}{l}\text { Zelenograd, } \\
\text { Panfilova street }\end{array}$} & 19.7.2014 & $\begin{array}{l}9 \text { empty cocoons, } 5 \text { adults in cocoons, } \\
2 \text { larvae in cocoons, } 4 \text { pupae }\end{array}$ & 13 & 9 \\
\hline & 16.6.2014 & 3 empty cocoons & 1 & 3 \\
\hline \multirow{3}{*}{ Planernaya } & 9.1 .2014 & 5 larvae in cocoons & 1 & 4 \\
\hline & 10.3 .2014 & 1 adult in cocoon, 7 larvae in cocoons & 2 & 3 \\
\hline & 28.4.2014 & 10 adults in cocoons & 12 & 0 \\
\hline Povarovka & 2.5 .2014 & 3 adults in cocoons, 6 larvae in cocoons & 6 & 1 \\
\hline $\begin{array}{l}\text { Moscow, Botanical } \\
\text { garden of VILAR }\end{array}$ & 19.6.2014 & 7 adults reared from cocoons & 2 & 9 \\
\hline Solnechnogorsk & 21.7 .2014 & 10 adults in cocoons, 2 larvae & 4 & 0 \\
\hline Total number & - & 55 adults, 7 pupae, 67 larvae & 56 & 51 \\
\hline
\end{tabular}




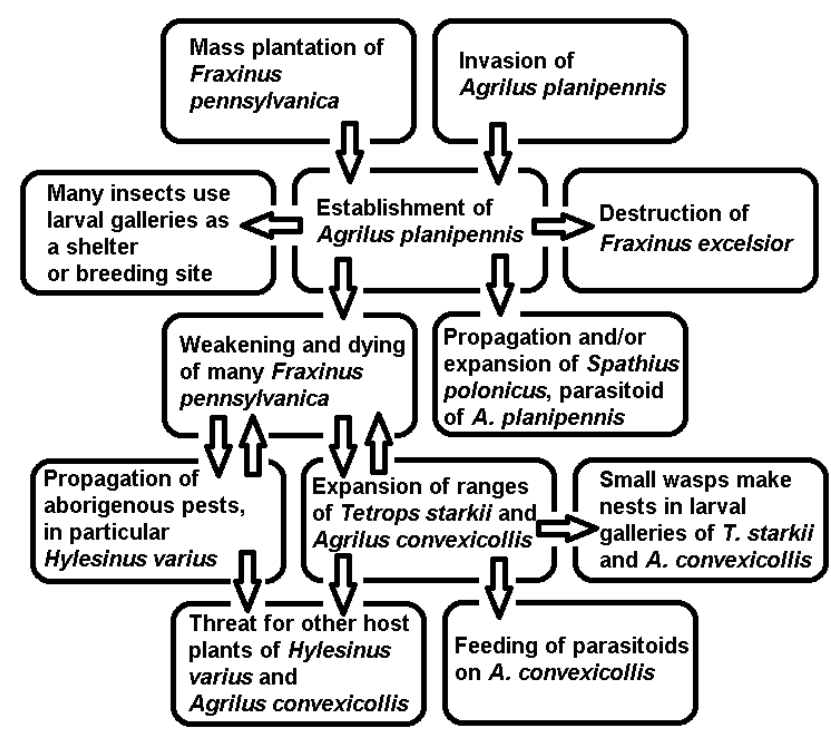

Fig. 5. Cascading ecological effects caused by the establishment of Agrilus planipennis.

2014). In central European Russia, the native F. excelsior is rare (Gubanov et al., 1992), but mass cultivation of North American $F$. pennsylvanica created a rich food supply for A. planipennis. This was one of the main factors aiding the establishment and quick propagation of this invasive pest. Few cases of damage to $F$. excelsior by $A$. planipennis were known before 2012. It was hoped that $F$. excelsior might be less susceptible to this pest (Baranchikov et al., 2008; Izhevskii \& Mozolevskaya, 2010) but unfortunately this is not so. Many cases of infestation and severe damage of F. excelsior are known (Majorov et al., 2012; Straw et al., 2013; Baranchikov et al., 2014 and present study). Fraxinus excelsior is common in the south of European Russia, the Caucasus and central and Western Europe. It has an important role in the biodiversity of European forests (Mitchell et al., 2014), so the ecological consequences of the establishment of $A$. planipennis in Europe could be considerable.

In the Far East, A. planipennis often affects trees together with Hylesinus chlodkovskyi Berger (Yurchenko et al., 2007). In European Russia, it often affects trees together with the native pest of the same genus: $H$. varius. The establishment of $A$. planipennis was accompanied by an outbreak of H. varius (Izhevskii \& Mozolevskaya, 2010).
This outbreak was recorded after 2002, i.e. before the first specimen of $A$. planipennis was found (Izhevskii, 2007). It is possible that $H$. varius thrived because $A$. planipennis weakened the ash trees, but it is also possible that the establishment of $A$. planipennis was facilitated by an outbreak of $H$. varius. It is known that native and alien xylophagous insect species can benefit each other by weakening trees (Kenis et al., 2009). An outbreak of $H$. varius worsens the situation for ash trees and can potentially also affect lilac (Syringa spp.) and other host plants of this species (Stark, 1952).

Examination of the ranges and habitats of T. starkii and A. convexicolis has led me to conclude that these West-Palaearctic xylophagous beetles are not native to central European Russia. First, they were not recorded there before the establishment of $A$. planipennis, but were discovered almost immediately after the establishment of $A$. planipennis. Second, they occur only on ash trees damaged by $A$. planipennis. Third, they occur only in habitats transformed by humans, which is typical of newly established non-native beetles (Beenen \& Roques, 2010). In Western Europe, T. starkii and A. convexicolis develop in dead branches of ash trees (Starzyk \& Lessaer, 1978; Brechtel \& Kostenbader, 2002). Probably they spread to European Russia because $A$. planipennis had weakened the ash trees growing there.

Could A. convexicollis and T. starkii have occurred unnoticed in central European Russia prior to the arrival of A. planipennis? It is unlikely, though impossible to prove the absence of any species of insect in any territory. However, the fauna of xylophagous beetles in the Moscow region has historically been intensively surveyed and $A$. convexicollis and T. starkii were not recorded (Nikitsky et al., 1996). Also, there are no specimens of $A$. convexicollis and T. starkii collected in central European Russia in the rich collections in the Zoological Institute (Russian Academy of Sciences), Moscow State Pedagogical University and Zoological Museum of Moscow State University, although there are many other specimens of the genera Agrilus and Tetrops and of beetles collected from ash trees, such as $H$. varius. In addition, $A$. convexicollis and $T$. starkii are conspicuous because they are neither very small nor nocturnal. They occur on the leaves of ash trees in cities where many professional and amateur entomologists live and where specialized institutions for forest science are located. Fi-

TABLE 6. Results of examinations of trees of Fraxinus excelsior in European Russia.

\begin{tabular}{lcccc}
\hline Localities & Dates & $\begin{array}{c}\text { No. of trees } \\
\text { examined }\end{array}$ & $\begin{array}{c}\text { No. of trees } \\
\text { with emergence holes }\end{array}$ & Source of information \\
\hline Moscow & 2013 & 14 & 7 & Straw et al., 2013 \\
Moscow, N.V. Tsitsin Main Botanical Garden & 2014 & 64 & 45 & Baranchikov et al., 2014 \\
Moscow, Botanical garden of VILAR & 19.6 .2014 & 16 & 16 & Own observations \\
Voronezh & 12.6 .2013 & 1 & 1 & Own observations \\
Tula & 5.6 .2013 & 3 & 3 & Own observations \\
Orel & $4 .-5.6 .2013$ & 14 & 8 & Own observations \\
\hline Total number & & 112 & 80 & \\
\hline
\end{tabular}


nally, $A$. convexicollis and $T$. starkii were recorded at hundreds of localities in West and Central Europe before 2007, but not in the centre of European Russia. It is unlikely that they occurred but remained unnoticed in the Moscow region since the fauna of beetles in the Moscow region is as well studied as the fauna of Central Europe.

Perhaps more insects were recorded on ash and their known distribution ranges extended after the detection of A. planipennis because people looked harder and in more places? That is not the case. First, T. starkii and A. convexicollis were recorded in the Yaroslavl region before the data on the detection of $A$. planipennis in central Russia were published (D. Vlasov, pers. commun.; Vlasov, 2010). Second, the researchers who collected $A$. convexicollis and T. starkii before 2013 (D. Vlasov, E. Shankhiza, M. Danilevsky) were not surveying ash trees in connection with the establishment of $A$. planipennis.

Fraxinus pennsylvanica is very common in the centre of European Russia, so there is no reason to think that the hosts in the centre of European Russia were less suitable than in Europe. In spite of this, in the 20th century, $T$. starkii and $A$. convexicollis were recorded at several hundred localities in Central and Western Europe but not in the Moscow region and other regions of Central Russia. There are no reasons to believe that these species were more difficult to find in the Moscow region than in Central Europe, so I believe that the absence of these species in collections and lists of fauna is reliable evidence of their absence before the $A$. planipennis invasion.

What factors could facilitate the spread of $A$. convexicollis and T. starkii into central European Russia? First, it is well known that many insects in Europe are now spreading northward because of warming climates (Beenen \& Roques, 2010). Second, the introduction of F. pennsylvanica created a rich food supply for these pests. The main factor is probably the weakening of ash trees by $A$. planipennis because the northern borders of their ranges shift northwards only in the region occupied by A. planipennis. Agrilus convexicollis and T. starkii extended their known ranges northwards by more than $600 \mathrm{~km}$ and just into areas recently occupied by $A$. planipennis. It is unlikely that it is just a coincidence. Larvae of xylophagous beetles can develop faster if the tree is stressed (Tluczek et al., 2011). In stressed trees, they can complete development even if the warm period is short. Therefore, if the shorter warm period was the factor limiting the northern extension of the ranges of $T$. starkii and $A$. convexicollis, the appearance of stressed ash trees could have facilitated the spread of these species to the north. Straw et al. (2013) discuss the possible influence of drought on the susceptibility of Fraxinus excelsior and $F$. pennsylvanica. Probably the severe drought in 2010 facilitated the current outbreak of $A$. planipennis and other xylophagous insects connected with ash trees.

It is quite possible that $T$. starkii and $A$. convexicollis could weaken $F$. pennsylvanica and therefore facilitate further propagation of $A$. planipennis. If this hypothesis is confirmed, the interactions between $A$. planipennis, $A$. convexicollis and T. starkii are an example of an invasion meltdown, i.e. the process by which a group of non-native species facilitate one another's invasion (Simberloff \& Von Holle, 1999). Agrilus convexicollis and T. starkii are known to feed on North American F. pennsylvanica, therefore they could potentially become established wherever $F$. pennsylvanica is present. The appearance of T. starkii and $A$. convexicollis, as well as the outbreak of the native pest $H$. varius, could affect $F$. excelsior in European Russia.

The parasitoid $S$. polonicus could also be a non-native species that spread into central European Russia shortly after the establishment of $A$. planipennis. It is rather widely distributed in the West Palaearctic, but was not recorded in central European Russia until after the establishment of $A$. planipennis. It is unlikely that $S$. polonicus was introduced with $A$. planipennis because $S$. polonicus is not recorded in the native range of $A$. planipennis, although less is generally known about the ranges of Braconidae than of many beetles. As a result, it cannot be excluded that $S$. polonicus may have occurred but remained unrecorded in central European Russia before its recent discovery.

I found $S$. polonicus under the bark at all localities where I collected larvae of $A$. planipennis. Obviously this parasitoid is common in the region occupied by A. planipennis. The level of parasitism by $S$. polonicus seems rather high, so this parasitoid could if propagated and released be an effective biological control agent of $A$. planipennis infestations, though more precise studies are necessary to evaluate this hypothesis. Spathius polonicus may be suitable for biocontrol of $A$. planipennis both in Europe and North America, because it is a native of the temperate climate zone. The potential of this parasitoid for biological control needs to be investigated further.

The resulting cascade of ecological effects following the spread of $A$. planipennis may also affect other species, because $T$. starkii, A. convexicollis and $S$. polonicus are connected with other species of insects and plants in their native ranges. In particular, $A$. convexicollis feeds on different trees and shrubs of the family Oleaceae (Brechtel \& Kostenbader, 2002) and larvae of S. polonicus are known to parasitize the larvae of many buprestids (Belokobylskij, 2003). In addition, there are parasitoids that parasitize $A$. convexicollis and T. starkii. Cascading ecological effects concern not only insects included in food chains connected with ash, but may affect some insects that use the space under loose bark as a shelter or breeding site.

Cascading direct and indirect effects of the establishment of $A$. planipennis are reported in North America (Smith, 2006; Gandhi \& Herms, 2010; Herms \& McCullough, 2014). The damage resulting from an outbreak of $A$. planipennis causes the formation of gaps in the canopy, changes woody debris dynamics and biogeochemical cycling, influencing both native and non-native plants. In particular, A. planipennis can facilitate the establishment and spread of invasive plants by creating gaps in the canopy that increase light availability while relaxing interspecific competition for space and resources.

It is known that invasion by one species can facilitate the invasion of a related species (for example, parasites) 
from the same region (Kenis et al., 2009), but the case considered in the present article is different. The community connected with $F$. pennsylvanica affected by A. planipennis is "intercontinental" and of recent origin. The host plant F. pennsylvanica originates from North America, while $A$. planipennis is from East Asia, T. starkii, A. convexicollis and probably $S$. polonicus are from European regions west and south of the centre of European Russia, and $H$. varius and other insects are indigenous. Ecological interactions between the members of this community are anthropogenic, because these are interactions between species that do not occur in the wild. This case illustrates that the invasion of one non-native species could indirectly affect the distributions of other species through cascading ecological effects. In other words, humanity inadvertently creates new complexes of ecologically related species and these complexes have unknown properties.

ACKNOWLEDGEMENTS. I thank M. Danilevsky (A.N. Severtsov Institute of Ecology and Evolution, Moscow), A. Miroshnikov (Russian Entomological Society, Krasnodar), D. Vlasov (Yaroslavl State Historical-Architectural and Art Museum-Reserve, Yaroslavl), V. Alekseev (Kaliningrad State Technical University, Kaliningrad) and G. Georgiev (Forest Research Institute, Sofia) for valuable information, S. Belokobylskij (Zoological Institute, St. Petersburg) for identification of Braconidae, K. Makarov (Moscow State Pedagogical University, Moscow) and M. Volkovitsh (Zoological Institute, St. Petersburg) for the possibility to study specimens from collections deposited in their respective institutes, to V. Maslyakov (All-Russian Research Institute of Medicinal and Aromatic Plants) for allowing me to collect insects in the botanical garden of this institute, and to N.W. Siegert (USDA Forest Service) and A.F.G. Dixon (University of Norwich) for linguistic corrections. The study was supported by the Russian Foundation for Basic Research (project No. 15-2902550).

\section{REFERENCES}

Anulewicz A.C., McCullough D.G., Cappaert D.L. \& Poland T.M. 2008: Host range of the emerald ash borer (Agrilus planipennis Fairmaire) (Coleoptera: Buprestidae) in North America: results of multiple-choice field experiments. - Environ. Entomol. 37: 230-241.

Aukema J.E., Leung B., Kovacs K., Chivers C., Britton K.O., Englin J., Frankel S.J., Haight G., Holmes T.P., Liebhold A.M., McCullough D.G. \& Von Holle B. 2011: Economic impacts of non-native forest insects in the continental United States. - PLOS ONE 6: e24587.

BARANCHIKOV Y.N. 2013: EAB is the main acronym in European forest protection in the first half of this century. In Selikhovkin A.V. \& Musolin D.L. (eds): Proceedings of the The Kataev Memorial Readings - VII. Pests and Disease of Woody Plants in Russia. Saint Petersburg State Forest Technical University, Saint Petersburg, pp. 8-9.

Baranchikov Y.N., Mozolevskaya E.G., Yurchenko G.I. \& KeNIS M. 2008: Occurrence of the emerald ash borer (Agrilus planipennis) in Russia and its potential impact on European forestry. - EPPO Bull. 38: 233-238.

Baranchikov Y.N., Seraya L.G. \& Grinash M.N. 2014: All European ash species are susceptible to emerald ash borer Agrilusplanipennis Fairmaire (Coleoptera: Buprestidae) - a Far Eastern invader. - Siber. Forest J. 6: 80-85.
BeEnen R. \& Roques A. 2010: Leaf and seed beetles (Coleoptera, Chrysomelidae). Chapter 8.3. - BioRisk 4: 267-292.

Belgian Species List 2014: Spathius polonicus Niezabitowski, 1910. http://www.species.be/en/8753. Accessed 29 March 2014.

Bellavista M., La Mantia T. \& Sparacio I. 2009: Il Tetrops starkii Chevrolat, 1859 in Sicilia (Coleoptera: Cerambycidae). — Natural. Sicil. (N.S.) 33: 487-257.

BelokobylskiJ S.A. 1989: The Palaearctic species of braconide wasps of the genus Spathius Nees: S. labdacus, S. urios and $S$. leucippus species group (Hymenoptera, Braconidae, Doryctinae). - Proc. Zool. Inst. USSR Acad. Sci. 188: 39-57.

Belokobylskij S.A. 2003: The species of the genus Spathius Nees, 1818 (Hymenoptera: Braconidae: Doryctinae) not included in the monograph by Nixon (1943). - Ann. Zool. 53: 347-488.

Bense U. 1995: Longhorn Beetles. Illustrated Key to the Cerambycidae and Vesperidae of Europe. Margraf Verlag, Weikersheim, iv $+512 \mathrm{pp}$.

Brechtel F. \& Kostenbader H. 2002: Die Pracht- und Hirschkäfer Baden-Württembergs. E. Ulmer, Stuttgart, 632 pp.

Brelih S., Drovenik B. \& Pirat A. 2006: Gradivo za favno hroščev (Coleoptera) Slovenije $2^{\text {nd }}$ contribution: Polyphaga: Chrysomeloidea (= Phytophaga): Cerambycidae. - Scopolia 58: $1-442$.

Cocquempot C.C. 2011: Tetrops starkii Chevrolat, 1859, espèce nouvelle pour le département d'Indre-et-Loire, France (Coleoptera, Cerambycidae). - Bull. Rutilans 14(2): 42-48.

Coleoptera Poloniae 2014: Tetrops starkii. http://coleoptera. ksib.pl/. Accessed 12 July 2014.

CSCF-KARCH 2013: Distribution of species. http://lepus.unine.ch/ carto/index.php?nuesp $=23007 \&$ rivieres $=$ on \&lacs $=$ on \&hillsh $=$ on\&year=1990. Accessed 14 November 2013.

DANILEVSKY M.L. 2012: Additions and corrections to the new Catalogue of Palaearctic Cerambycidae (Coleoptera) edited by I. Löbl and A. Smetana, 2010. Part. VI. - Humanit. Sp. Int. Alm. 1: 900-943.

Danilevsky M.L. 2014: Catalogue of Palaearctic Cerambycoidea. http://www.zin.ru/Animalia/Coleoptera/rus/cer_edit.htm. Accessed 17 May 2014.

Danmarks Fugle og Natur 2014: Tetrops starkii. www.fugleognatur.dk. Accessed 11 July 2014.

Drumont A., Baugnee J. \& Minet G. 2012: Note sur la présence en Belgique de Tetrops starkii Chevrolat, 1859 (Coleoptera, Cerambycidae, Lamiinae). - Lambillionea 52: 167-170.

Elton C.S. 1966: Dying and dead wood. In The Pattern of Animal Communities. Springer, Dordrecht, pp. 279-305.

Emerald Ash Borer Information 2014: Emerald Ash Borer. http://www.emeraldashborer.info/. Accessed 15 September 2014.

Eyre D., Anderson H., BAKer R. \& CANnon R. 2013: Insect pests of trees arriving and spreading in Europe. - Outlooks Pest Manag. 24: 176-180.

FAgdataCenter FOR Biodiversitet OG TERRESTRISK NATUR 2007: Tetrops starkii. http://thor.dmu.dk/1_Om_DMU/2_Tvaer-funk/3_ fdc_bio/projekter/redlist/data.asp? $\mathrm{ID}=\overline{7} 84 \&$ gruppeID $=33$. Accessed 20 May 2014.

FRAXIGEN 2005: Ash Species in Europe: Biological Characteristics and Practical Guidelines for Sustainable Use. Oxford, Oxford Forestry Institute, $128 \mathrm{pp}$.

GandHI J.K.J. \& Herms D.A. 2010: Direct and indirect effects of alien insect herbivores on ecological processes and interactions in forests of eastern North America. - Biol. Invas. 12: 389-405. 
GBIF 2013: Global Biodiversity Information Facility (LI, Biological Records Centre, Suffolk Biological Records Centre, NEF，IFR-DNF，ArtDatabanken). http://www.gbif.org/. Accessed 14 November 2013.

Geiser E. 2001: Die Käfer des Landes Salzburg. Faunistische Bestandserfassung und tiergeographische Interpretation. Monographs on Coleoptera, Vol. 2. Zoologisch-Botanische Ges. in Österreich, Wien, 706 pp.

Georgiev G., Doychev D. \& Migliaccio E. 2005: Studies on Cerambycid fauna (Coleoptera: Cerambycidae) in Western Rhodopes in Bulgaria. - For. Sci. 2: 81-90.

Gnjatović I. \& Žıirić V. 2010: Cerambycids of Southeast Serbia (Coleoptera, Cerambycidae). - Biol. Nyssana 1: 111-115.

Gubanov I.A., Kiseleva V.S., Novikov V.S. \& Tikhomirov V.N., 1992: Key to Identification of Vascular Plants of Central European Russia. Moscow State University, Moscow, 400 pp.

Hellrigl K., Deiaco C., v. Mörl G. \& Niederfriniger E. 2012 Neue Checklist zur Bockkäfer-Fauna Südtirols (Coleoptera: Cerambycidae). - For. Observer 6: 207-238.

Herms D.A. \& McCullough D.G. 2014: Emerald ash borer invasion of North America: history, biology, ecology, impacts, and management. - Annu. Rev. Entomol. 59: 13-30.

Hismans R.J. 2011: DIVA-GIS, Ver. 7.5. http://www.diva-gis.org/. Accessed 25 June 2015.

Holzschun C. 1981: Beitrag zur Kenntnis der europäischen Tetrops-Arten (Cerambycidae, Col.). — Koleopterol. Rundsch. 55: $77-89$.

Horion A. 1974: Faunistik der mitteleuropäischen Käfer 12. Cerambycidae - Bockkafer. By the Author, Uberlingen-Bodensee, $\mathrm{xvi}+228 \mathrm{pp}$.

Hoskovec M. 2007: Tetrops starkii Chevrolat, 1859 in Longhorn beetles (Cerambycidae) of the West Palaearctic region presented by Michal Hoskovec and Martin Rejzek. http://www.cerambyx.uochb.cz/tetstark.htm. Accessed 11 July 2014.

IzHEVSKII S.S. 2007: Threatening findings of emerald ash borer Agrilus planipennis in Moscow region. http://www.zin.ru/Animalia/Coleoptera/rus/agrplaiz.htm. Accessed 20 September 2014.

Izhevskit S.S. \& Mozolevskaya E.G. 2010: Agrilus planipennis Fairmaire in Moscow ash trees. - Rus. J. Biol. Invas. 1: $153-155$.

JENDEK E. 1994: Studies in the East Palaearctic species of the genus Agrilus Dahl, 1823 (Coleoptera: Buprestidae). Part I. Entomol. Probl. 25: 9-25.

Kenis M., Auger-Rozenberg M.A., Roques A., Timms L., Péré C., Cock M.J. \& Lopez-VAamonde C. 2009: Ecological effects of invasive alien insects. In: Ecological Impacts of Non-Native Invertebrates and Fungi on Terrestrial Ecosystems. Springer, Dordrecht, pp. 21-45.

LAMIAIRES DU Monde 2014: Tetrops starkii. http://www.lamiinae. org $/ 73 \mathrm{v} /$ index.php?pg=coll\&id=420\&lg=en. Accessed 12 July 2014.

Löbl I. \& Smetana A. 2010: Catalogue of Palaearctic Coleoptera 6. Apollo Books, Stenstrup, $924 \mathrm{pp}$.

LőKKÖs A. 2010: A Nagy-Berek Cincérei (Coleoptera: Cerambycidae). In XVI. ITF Conference in Keszthely, Keszthely, pp. $1-6$.

Majorov S.R., Bochkin V.D., Nasimovich Y.A. \& Shcherbakov A.V. 2012: Alien Flora of Moscow and Moscow Region. KMK, Moscow, $412 \mathrm{pp}$.

Migliaccio E., Georgiev G. \& Gashtarov V. 2007: An annotated list of Bulgarian Cerambycids with special view on the rarest species and endemics (Coleoptera: Cerambycidae). — Lambillionea (Suppl.) 107: 3-78.
Mitchell R.J., Beaton J.K., Bellamy P.E., Broome A., Chetcuti J., Eaton S., Ellis C.J., Gimona A., Harmer R., Hester A.J., Hewison R.L., Hodgetts N.G., Iason G.R., KerR G., Littlewood N.A., Newey S., Potts J.M., Pozsgai G., Ray D., Sim D.A., Stockan J.A., Taylor A.F.S. \& Woodward S. 2014: Ash dieback in the UK: A review of the ecological and conservation implications and potential management options. - Biol. Conserv. 175: 95-109.

Mozolevskaya E.G., Selikhovkin A.V., IzHEvskiI S.S., ZaKharov A.A., Golosova M.A. \& Nikitsky N.B. 2010: Forest Entomology. Akademia, Moscow, 416 pp.

NIKITSKY N.B. 2009: New and interesting finds of xylophilous and some other beetles (Coleoptera) in the Moscow region and in Moscow. - Bull. Soc. Nat. Mosc. 114(5): 50-58.

Nikitsky N.B., Osipov I.N., Chemeris M.V., Semenov V.B. \& Gusakov A.A. 1996: [Coleoptera: Xylobionts, Mycetobionts, and Scarab Beetles of the Prioksko-Terrasny Nature Biosphere Reserve.] Archives of Zoological Museum of Moscow State University 36. Moscow State University, Moscow, 197 pp. [in Russian].

Nikitsky N.B., BiBin A.R. \& Dolgin M.M. 2008: Xylophilous beetles (Coleoptera) of the Caucasian State Biospheric Natural Reserve and Adjacent Territories. Russian Academy of Sciences, Syktyvkar, 254 pp.

Orlova-Bienkowskaja M.J. 2013: Dramatic expansion of the range of the invasive ash pest, buprestid beetle Agrilus planipennis Fairmaire, 1888 (Coleoptera, Buprestidae) in European Russia. - Entomol. Rev. 93: 1121-1128.

Orlova-BienkowsKaja M.J. 2014a: Ashes in Europe are in danger: the invasive range of Agrilus planipennis in European Russia is expanding. - Biol. Invas. 16: 1345-1349.

Orlova-BienKowSKaja M.J. 2014b: European range of the emerald ash borer Agrilus planipennis (Coleoptera: Buprestidae) is expanding: The pest destroys ashes in the northwest of Moscow Oblast and in part of Tver Oblast. - Russ. J. Biol. Invas. 5: $32-37$.

Orlova-BienkowsKaja M.J. \& Belokobylskij S.A. 2014: Discovery of the first European parasitoid of the emerald ash borer Agrilus planipennis (Coleoptera: Buprestidae). — Eur. J. Entomol. 111: 594-596.

Orlova-Bienkowskaja M.J. \& Volkovitsh M.G. 2014: Range expansion of Agrilus convexicollis in European Russia expedited by the invasion of emerald ash borer, Agrilus planipennis (Coleoptera: Buprestidae) - Biol. Invas. 17: 537-544.

Richardson D.M., Pyšek P., Rejmánek M., Barbour M.G., PANETTA F.D. \& WeST C.J. 2000: Naturalization and invasion of alien plants: concepts and definitions. - Divers. Distrib. 6: 93-107.

Roubal J. 1929: Koleopterologische Notizen. - Entomol. Anz. 9: $354-355$.

SAMA G. \& RApuzzI P. 2011: Una nuova checklist dei Cerambycidae d'Italia. - Quad. Stud. Not. St. Nat. Romagn. 32: 121-164.

Schmeltz B. 2002: Présence dans le Haut-Rhin de Tetrops starkii Chevrolat, 1859 (Coleoptera, Cerambycidae). — Bull. Soc. Entomol. Mulhouse 58: 3 .

SERAFIM R. 2010: The catalogue of the palaearctic species of Lamiinae (Coleoptera: Cerambycidae) from the patrimony of "Grigore Antipa" National Museum of Natural History (Bucharest) (Part V). - Trav. Mus. Nat. Hist. Nat. "Grigore Antipa" 53: 235-272.

Siegert N.W., McCullough D.G., Liebhold A.M. \& Telewski F.W. 2014: Dendrochronological reconstruction of the epicentre and early spread of emerald ash borer in North America. Divers. Distrib. 20: 847-858. 
Simberloff D. \& Von Holle B. 1999: Positive interactions of nonindigenous species: invasional meltdown? - Biol. Invas. 1: $21-32$.

SLÁMA M. 1998: [Longhorn Beetles - Cerambycidae of the Czech Republic and Slovak Republic (Beetles - Coleoptera).] By the author, Krhanice, 383 pp. [in Czech, general chapters bilingual Czech/German].

Sмiтн A. 2006: Effects of Community Structure on Forest Susceptibility and Response to the Emerald Ash Borer Invasion of the Huron River Watershed in Southeastern Michigan. MS Thesis, The Ohio State Univ., Columbus, 122 pp.

Sobrino M.Á.S. \& SÁnchez L.T. 2003: Tetrops starki Chevrolat, 1859: un nuevo cerambícido para la fauna Ibérica (Coleoptera: Cerambycidae). - Bol. SEA 32: 69-71.

STARK V.N. 1952: Fauna of the USSR. 31. Bark Beetles. Izdatelstvo Akademii Nauk, Moscow, Leningrad, 463 pp.

StARZYK J.R. \& Lessaer M. 1978: Studies on the distribution, morphology and biology of Tetrops starki Chevr. (Coleoptera, Cerambycidae). - Z. Angew. Entomol. 86: 35-46.

Straw N.A., Williams D.T., Kulinich O. \& Gninenko Y.I. 2013 Distribution, impact and rate of spread of emerald ash borer Agrilus planipennis (Coleoptera: Buprestidae) in the Moscow region of Russia. - Forestry 86: 515-522.

Tamutis V., Tamutė B. \& Ferenca R. 2011: A catalogue of Lithuanian beetles (Insecta, Coleoptera). — ZooKeys 121: 1-494.

Tluczek A.R., McCullough D.G. \& Poland T.M. 2011: Influence of host stress on emerald ash borer (Agrilus planipennis Fairmaire) (Coleoptera: Buprestidae) adult density, development, and distribution in Fraxinus pennsylvanica trees. - Environ. Entomol. 40: 357-366.
Vinogradova Y.K., Mayorov S.R. \& Khorun L.V. 2010: Black Book of Central Russia Flora (Alien Plant Species in the Ecosystems of Central Russia). GEOS, Moscow, 502 pp.

VLAsov D.V. 2010: Xylophilous beetles, pests of green plantations of Yaroslavl. In: Proceedings of IV Interregional Scientific and Practical Conference "Ecology and Culture: From the Past to the Future". Indigo, Yaroslavl, pp. 156-162.

Volkovitsh M.G. \& Mozolevskaya E.G. 2014: The tenth "anniversary" of the invasion of ermerald ash borer Agrilus planipennis Fairm. (Coleoptera: Buprestidae) invasion in Russia: results and prospects. - Izv. St.-Peterbg. Lesoteh. Akad. 207: 8-19.

WAARNEMING.NL 2014: Tetrops starkii. http://waarneming.nl/ soort/view/22502? from $=1900-04-18 \&$ to $=2014-04-18 \&$ spe cies $=$ soort $+22502 \&$ prov $=0 \&$ maand $=0 \&$ os $=0 \&$ prov_wg $=0$ $\&$ rows $=20 \&$ references $=0 \&$ waardplant $=0 \&$ poly $=1 \&$ hide hidden $=0$ \&page $=0$. Accessed 12 July 2014 .

Wei X., Wu Y., Reardon R., Sun T.-H., Lu M. \& Sun J.-H. 2007: Biology and damage traits of emerald ash borer (Agrilus planipennis Fairmaire) in China. - Insect Sci. 14: 367-373.

WelCh R.C. 2003: Monks Wood Coleoptera - an update: 19732003. In Gardiner C. \& Sparks T. (eds): Ten Years of Change: Woodland Research at Monks Wood NNR, 1993-2003. Proceedings of the 50th Anniversary Symposium, December 2003. Northminster House, Peterborough, pp. 111-127.

Yurchenko G.I., Turova G.I. \& KuZmin E.A. 2007: To distribution and ecology of emerald ash borer (Agrilus planipennis Fairmaire) in the Russian Far East. In A.I. Kurentsov's Annual Memorial Meetings. 18. Dalnauka, Vladivostok, pp. 94-98.

Received April 15, 2015; revised and accepted July 13, 2015 Prepublished online October 8, 2015 